\title{
ANALISIS FAKTOR INTERNAL - EKSTERNAL DAN STATUS KEBERLANJUTAN PENGELOLAAN PERIKANAN TANGKAP DI TELUK JAKARTA
}

\author{
(Internal and External Factors Analysis and Sustainable Status of \\ Capture Fisheries Management in Jakarta Bay)
}

\author{
Siti Radarwati'12, Mulyono S. Baskoro ${ }^{3}$, Daniel R. Monintja ${ }^{3}$, Ari Purbayanto ${ }^{3}$ \\ PT. Ting Sheen Bandascjahtera \\ Artha Graha Bld, 6th Floor Jl.Sudirman Kav 52-53 - Jakata \\ Phone:(62-21)5152107, Fax:(62-21)5152109
}

\begin{abstract}
The capture fishery at Jakearta Bay has a big role in increasing the economy and community life at the site, but its not only faced the decreasing fishery production and high poluted water teritory, its sometime confronted with the conservation function located in Kepulauan Seribu. The objectives of this reasearch were to determine internal and external factors that effects to capture fishery activity, to identify sustainable status of capture fishery management in Jakarta Bay and its development management strategy. The study used the methods of IFAS, EFAS and SFAS matrix analysis, IE matrix analysis and SWOT matrix analysis. The result revealed that there are 17 (seventeen) factors affecting the capture fishery activities in Teluk Jakarta at the point of view dimensions of ecological, biological, economic, social and technological. The scores output from matrix IFAS, EFAS and SFAS were all categorized as "kurang baik" with total score 2,529 for internal factors and 2.747 for external factor, and 2.152 for SFAS, respectively. The sustainable status for capture fishery management in Teluk. Jakarta pointed out by IE matrix in the cell $V$ categorized as developing status that need horizontally concentration strategy. The study identified that there are several important strategies to support the management sustainability of capture fishery : human resources empowerment, quality product improvement, increasing fishermen capability, increasing capture fishery activities supervision, extension for fishermen, integrated management to preserve the functions of water ecosystem, small scale fishery standardization and fishing days opreration management by implementing closed - open seasons.
\end{abstract}

Keywords : internal-extenal factors, management sustainability, capture fishery

\begin{abstract}
ABSTRAK
Perikanan tangkap di Teluk Jakarta sangat berperan dalam mengangkat perekonomian dan kehidupan masyarakat di lokasi, namun selain produksi perikanan yang cenderung menurun dan tingkat pencemaran yang tinggi di perairannya, terkadang aktifitas perikanan tangkap berbenturan dengan fungsi konservasi di Kepulauan Seribu. Penelitian ini bertujuan menentukan faktor internal dan eksternal pengelolaan, identifikasi status keberlanjutan kebijakan pengelolaan perikanan tangkap di Teluk Jakarta dan strategi pengembangan pengelolaannya. Metode yang digunakan dalam penelitian adalah analisis matriks IFAS, EFAS dan SFAS, analisis matriks IE, dan analisis matriks SWOT. Hasil analisis menunjukkan terdapat 17 (tujuh belas) faktor yang mempengaruhi kegiatan perikanan tangkap di Teluk Jakarta baik dari dimensi ekologi, biologi, ekonomi, sosial maupun teknologi. Hasil skor matriks IFAS,EFAS dan SFAS seluruhnya termasuk kategori "kurang baik" dengan total skor berturut-turut 2,529 untuk faktor internal, 2,747 untuk faktor eksternal dan 2.152 untuk SFAS. Status keberlanjutan pengelolaan perikanan tangkap di Teluk Jakarta ditunjukkan dalam matriks IE berada pada sel V, dikategorikan dalam tahap pertumbuhan yang memerlukan strategi konsentrasi secara horizontal. Beberapa strategi yang penting mendukung keberlanjutan pengelolaan tersebut adalah pemberdayaan SDM, peningkatan kualitas produk, peningkatan kemampuan nelayan mandiri, peningkatan pengawasan melekat, penyuluhan kepada nelayan, manajemen terpadu untuk mempertahankan fungsi ekosistem perairan, standarisasi terhadap perikanan skala kecil, dan pengaturan hari operasi dengan penerapan closed-open season.
\end{abstract}

Kata kunci : faktor internal-eksternal, keberlanjutan pengelolaan, perikanan tangkap

\section{PENDAHULUAN}

Perairan Teluk Jakarta mempunyai posisi strategis sebagai wilayah perairan DKI Jakarta, Ibukota Negara Indonesia serta merupakan pasar potensial berbagai aktivitas perikanan tangkap merupakan salah satu usaha dari sektor perikanan dan kelautan, serta merupakan salah sektor yang diandalkan untuk mengangkat perekonomian dan kesejahteraan nelayan dan pesisir (Muchtar, 1999).

\footnotetext{
${ }^{1}$ Corresponding author

${ }^{2}$ Sekretaris PT. Ting Sheen Bandascjahtera

${ }^{3}$ Staf Pengajar Departemen Pemanfaatan Sumberdaya Perikanan, FPIK-IPB
} 
usaha termasuk perikanan tangkap. Usaha

Perikanan tangkap di Teluk Jakarta merupakan kegiatan usaha penting bagi kehidupan masyarakat Jakarta Utara dan Kepulauan Seribu dikarenakan kegiatan perikanan baik budidaya maupun tangkap sudah merupakan budaya bahari yang melekat. Berbagai sarana dan prasana telah dibangun untuk menunjang aktivitas perikanan antara lain pelabuhan perikanan samudera dan beberapa lokasi pendaratan ikan di pantai Utara Jakarta. Namun demikian, produksi perikanan tersebut menurun cukup drastis, yaitu mencapai 38 persen sejak tahun 2002 (Sonari, 2009). Disamping itu, tingkat pencemaran di perairan Teluk Jakarta semakin tinggi yang berasal selain dari sampah juga berasal dari tumpahan minyak (Pemkab. Kep. Seribu, 2009), dan konflik penggunaan lahan wilayah pesisir juga sering terjadi (Rudianto, 2004) sehingga mengancam keberlanjutan kegi-atan perikanan tangkap di lokasi (Anna, 2003).

Sebagai upaya menciptakan pengelolaan berkelanjutan, maka berbagai faktor yang mempengaruhi baik secara internal maupun eksternal perlu diidentifikasi serta status keberlanjutan kebijakan pengelolaan perikanan tangkap tersebut juga perlu diketahui agar dapat dilakukan perbaikan ke arah yang lebih baik.

Tujuan penelitian :

a. Menentukan faktor internal dan eksternal yang mempengaruhi pengelolaan perikanan tangkap di Teluk Jakarta.

b. Menganalisis tingkat keberlanjutan kebijakan pengelolaan perikanan tangkap di Teluk Jakarta dan strategi pengembangan pengelolaannya.

Hipotesis penelitian :

a. Terdapat faktor-faktor yang mempengaruhi secara multidimensi terhadap pengelolaan dan aktivitas perikanan tangkap di Teluk Jakarta.

b. Pengelolaan perikanan tangkap di Teluk Jakarta saat ini belum mengakomodasi berbagai faktor penting yang mempengaruhi pengelolaan yang berkelanjutan.

\section{METODOLOGI}

\subsection{Waktu dan Tempat Penelitian}

Penelitian ini dilaksanakan selama satu tahun dimulai dari bulan Maret 2009 sampai dengan Maret 2010. Tempat penelitian adalah perairan Teluk Jakarta yang merupakan wilayah perairan Kota Jakarta Utara dan Kabupaten Administratif Kepulauan Seribu.

\subsection{Jenis Data dan Metode Pengum- pulan Data}

Jenis Data yang Dikumpulkan

Data yang dikumpulkan dalam penelitian ini terdiri dari data primer dan data sekunder mencakup data produksi perikanan, alat tangkap, sosial ekonomi dan budaya, kelembagaan, peraturan penangkapan, wilayah operasi penangkapan, kondisi lingkungan perairan, dan lainnya.

\section{Metode Pengumpulan Data}

Data primer seperti data sosial ekonomi, kondisi perairan, produksi, alat tangkap, wilayah operasi dan lainnya dikumpulkan melalui pengamatan langsung, wawancara dan pengisian kuesioner. Data sekunder dikumpulkan melalui penelusuran berbagai hasil studi, buku/literatur, informasi internet, referensi, statistik, terbitan jurnal, surat kabar, dan sumber lainnya yang mendukung. Wawancara dan pengisian kuesioner dilakukan terhadap responden yang merupakan pihak-pihak yang mewakili berbagai unsur yaitu pemerintah daerah dan pusat, pengusaha dan nelayan, LSM, pakar/tokoh masyarakat serta perguruan tinggi, yang memahami pengelolaan perikanan dan/ atau mengetahui kegiatan perikanan tangkap di lokasi. Khusus untuk responden yang berasal dari nelayan atau pelaku usaha perikanan tangkap dipilih secara purposive berdasarkan ketokohan, jenis usaha perikanan, dan jenis alat tangkap yang digunakan di perairan Teluk Jakarta.

\subsection{Metode Analisis Data}

\subsubsection{Analisis matriks IFAS, EFAS dan SFAS}

Analisis matriks Internal Factors Analysis Strategy (IFAS) dan External Factors Analysis Strategy (EFAS) dilakukan untuk pemetaan kondisi pengelolaan perikanan tangkap di perairan Teluk Jakarta dari segi internal dan eksternal baik menyangkut dimensi ekologi, biologi, ekonomi, sosial dan teknologi. Analisis matriks IFAS dan EFAS menghasilkan skor yang menunjukkan seberapa besar kontribusi atau pengaruh setiap faktor terhadap perikanan tangkap di Teluk Jakarta yang dikategorikan kedalam kekuatan, kelemahan, peluang, dan anca- 
man, dimana masing-masing kategori dipilah berdasarkan dimensi ekologi, biologi, ekonomi, sosial dan teknologi. Faktorfaktor yang merupakan uraian dari setiap dimensi yang dianggap penting dan berpengaruh didapat dari hasil wawancara dan pengisian kuesioner. Pengembangan matriks IFAS dan EFAS (Rangkuti, 2008) adalah sebagai berikut :

(1) Pengembangan matriks IFAS, yaitu kegiatan menentukan faktor-faktor strategis internal, memuat tentang kekuatan dan kelemahan lengkap dengan hasil analisis bobot, rating dan skornya;

(2) Pengembangan matriks EFAS, yaitu kegiatan menentukan peluang dan ancaman lengkap dengan hasil analisis bobot, rating dan skornya (matriks EFAS);

Untuk memudahkan analisis, penilaian dibagi dalam tiga jenis, yaitu bobot, rating, dan skor. Bobot menunjukkan tingkat kepentingan pengelolaan perikanan tangkap terhadap faktor tersebut dengan nilai berkisar 0 - 1 , dimana 0 menunjukkan tidak penting dan 1 menunjukkan sangat penting. Rating menunjukkan tingkat pengaruh yang secara nyata yang dapat diberikan oleh faktor tersebut terhadap pengelolaan perikanan tangkap dengan nilai berkisar 1 - 4, dimana $1,2,3$, dan 4 berturut-turut rendah, biasa, tinggi, dan sangat tinggi. Nilai rating untuk faktor kelemahan dan ancaman diberi secara terbalik, yaitu bila pengaruh rendah diberi nilai 4 dan pengaruh sangat tinggi diberi nilai 1. Sedangkan skor menyatakan tingkat/skor pengaruh positif (spp) sesuai kepentingan pengelolaan perikanan tangkap terhadap faktor yang dimaksud.

Dari tabel IFAS dan EFAS dipilih fakor-faktor yang memiliki skor yang tinggi untuk kekuatan dan peluang, dan dipilih faktor-faktor yang memiliki skor yang rendah untuk kelemahan dan ancaman atau merupakan faktor negatif yang sangat berpengaruh terhadap perikanan tangkap di Teluk Jakarta.

Setelah dipilih dituangkan dalam matrik SFAS (Strategic Factor Analysis Summary) yang merupakan matrik ringkasan/rangkuman dari kekuatan, kelemahan, peluang dan ancaman dengan tujuan untuk lebih memudahkan memformulasikan strategi. Matriks SFAS memberikan kepada para pengambil keputusan suatu rangkuman dari kekuatan, kelemahan, peluang dan ancaman untuk memudahkan memformulasikan strategi.
Jumlah skor pembobotan dari matrix IFAS, EFAS dan SFAS menunjukkan seberapa besar respon dari pengelolaan perikanan tangkap di Teluk Jakarta terhadap lingkungan eksternal dan internalnya (Wheelen, Hunger, 2002 diacu dalam Radarwati, 2003).

Indikator jumlah skor pembobotan (Wheelen, Hunger, 2002 diacu dalam Radarwati, 2003) dan hasil olah data adalah sebagai berikut :

1) Nilai $5=$ baik sekali

2) Nilai 4 = diatas rata-rata atau baik

3) Nilai 3 = rata-rata atau cukup baik

4) Nilai 2 = dibawah rata-rata atau tidak baik

5) Nilai $1=$ buruk

\subsubsection{Analisis matriks internal-ekster-nal (IE)}

Analisis matriks internal-eksternal (IE) merupakan kegiatan penentuan arah dan sasaran pengelolaan (Roger, 1990). Pengembangan matriks internal-eksternal (IE) dilakukan dengan mengidentifikasi kesesuaian kondisi pengelolaan dengan sembilan sel strategi pengelolaan yang digunakan dalam analisis SWOT. Sel tersebut adalah sel I, II, III, IV, V, VI, VII, VIII, dan IX yang berturut-turut menyatakan I (strategi pertumbuhan dengan konsentrasi pada integrasi vertikal), II (strategi pertumbuhan dengan konsentrasi pada integrasi horizontal), III (strategi penciutan atau turnaround), IV (strategi stabilitas), V (strategi pertumbuhan dengan konsentrasi pada integrasi horizontal), VI (strategi divestasi atau pengurangan), VII (strategi pertumbuhan melalui diversifikasi konsentrik), VIII (strategi pertumbuhan melalui konsentrasi konglomerasi), dan IX (strategi likuidasi). Setiap sel mempunyai kisaran nilai faktor internal dan faktor eksternal. Posisi dan arah pengelolaan dipilih dengan mencocokkan total skor faktor internal (matriks IFAS) dan faktor eksternal (matriks EFAS) dengan kisaran nilai pada sel.

\subsubsection{Analisis matriks SWOT}

Matriks SWOT digunakan untuk merumuskan beberapa alternatif strategi yang tepat untuk mendukung pengembangan pengelolaan perikanan tangkap ke arah yang lebih baik. Dalam analisis SWOT ini, faktor-faktor yang menjadi kekuatan (strength), kelemahan (weak-nesses), peluang (opportunity) dan ancaman (threat) dikombinasikan sehingga didapatkan beberapa alternatif keputusan (Rangkuti, 2008 
dan Cochrane, 2002). Adapun bentuk kombinasi tersebut adalah:

a. Kombinasi kekuatan (strength) dengan peluang (opportunity).

b. Kombinasi kekuatan (strength) dengan ancaman (threat).

c. Kombinasi kelemahan (weaknesses) dengan peluang (opportunity).

d. Kombinasi kelemahan (weaknesses) dengan ancaman (threat).

\section{HASIL DAN PEMBAHASAN}

\subsection{Dimensi Pengelolaan Perikanan Tangkap}

Hasil analisis data, dimensi ekologi, biologi, ekonomi, sosial dan teknologi merupakan lima komponen dasar yang menjadi acuan tingkat keberlanjutan pengelolaan perikanan tangkap di Teluk Jakarta.

\subsection{Pengelompokkan Komponen Dasar Secara Internal dan Eksternal}

Dari setiap komponen dasar diuraikan faktor-faktor yang dikelompokkan dalam lingkungan internal yang menjadi kekuatan dan kelemahan adalah:

1) Kekuatan (strength) terdiri dari sumberdaya ikan, potensi serta kegiatan konservasi sumber daya itu sendiri, sumberdaya manusia di bidang perikanan, sarana dan prasarana, modal, kapal dan teknologinya, pendapatan nelayan maupun peraturan. Kekuatan ini dapat dioptimalkan untuk meminimalisasi ancaman. Karena ini berasal dari internal sistem perikanan tangkap, aplikasinya memungkinkan untuk direncanakan dengan baik.

2) Kelemahan (weakness) terdiri dari tingkat produktifitas, rendahnya pengetahuan nelayan, konflik, belum adanya standarisasi kapal dan peraturan yang perlu namun belum tersedia. Kelemahan ini berasal dari dalam sistem perikanan tangkap yang dibutuhkan untuk dikembangkan namun tidak dimiliki atau sangat kurang. Untuk tidak menjadi hambatan, kelemahan ini dapat diminimalisasi sehingga tidak menjadi dampak yang negatif terhadap sistem.

Tabel 1 (matriks IFAS) menyajikan tingkat pengaruh dimensi ekologi, biologi, ekonomi, sosial dan teknologi yang telah dikelompokkan dalam lingkungan internal. Hasil perkalian bobot dan rating merupakan gambaran tingkat kontribusi atau pengaruh dari faktor-faktor internal, baik yang menjadi kekuatan maupun kelema- han dalam pengelolaan perikanan tangkap di Teluk Jakarta.

Hasil analisis lingkungan eksternal terhadap komponen dasar yang telah dikelompokkan menjadi peluang dan ancaman adalah :

1) Peluang (opportunity) terdiri dari program pemerintah yang mendukung penyelamatan terumbu karang, upaya konservasi, tingginya permintaan pasar, letak strategis, kegiatan promosi oleh pemerintah maupun swasta, iklim investasi, kondisi sosial politik dan perkembangan teknologi.

2) Ancaman (threat) terdiri dari peraturan pemerintah yang berdampak konflik, pencemaran, degradasi fungsi ekosistem perairan, punah atau berkurangnya spesies ikan baik dalam jumlah maupun mengecilnya ukuran ikan hasil tangkapan, faktor musiman yang mempengaruhi harga ikan, dan penggunaan alat tangkap yang destruktif.

Tabel 2 (matriks EFAS) menyajikan tingkat pengaruh dimensi ekologi, biologi, ekonomi, sosial dan teknologi yang telah dikelompokkan dalam lingkungan eksternal. Hasil perkalian bobot dan rating pada Tabel 2 tersebut merupakan gambaran tingkat kontribusi atau pengaruh dari faktor-faktor eksternal yang ada, baik yang memberi peluang maupun yang menjadi ancaman pengelolan perikanan tangkap di Teluk Jakarta.

Tabel 3 (matriks SFAS) menyajikan ringkasan dari matriks IFAS dan EFAS yang telah dipilih berdasarkan skor tertinggi untuk faktor kekuatan dan ancaman, dan skor terendah untuk faktor kelemahan dan ancaman. Tabel 3 menunjukkan tujuh belas faktor dominan yang mempengaruhi pengelolaan perikanan tangkap di Teluk Jakarta baik dari dimensi ekologi, biologi, ekonomi, sosial maupun teknologi.

Analisis faktor internal, kekuatan yang dominan adalah pada dimensi sosial berupa ketersediaan tenaga kerja di sektor perikanan, sedang faktor kelemahan yang dominan adalah dari dimensi ekologi yaitu kurangnya pengetahuan dari pelaku perikanan tangkap tentang jumlah SDI yang diperbolehkan. Analisis faktor eksternal, peluang yang dominan adalah dari dimensi ekonomi yaitu tingginya permintaan akan komoditi perikanan sebagai peluang pasar, sedangkan fakor ancaman yang dominan adalah dimensi ekologi yaitu 
degradasi ekosistem laut dan pesisir akibat alih fungsi lahan.

Tabel 1. Matriks Faktor Strategi Internal (IFAS)

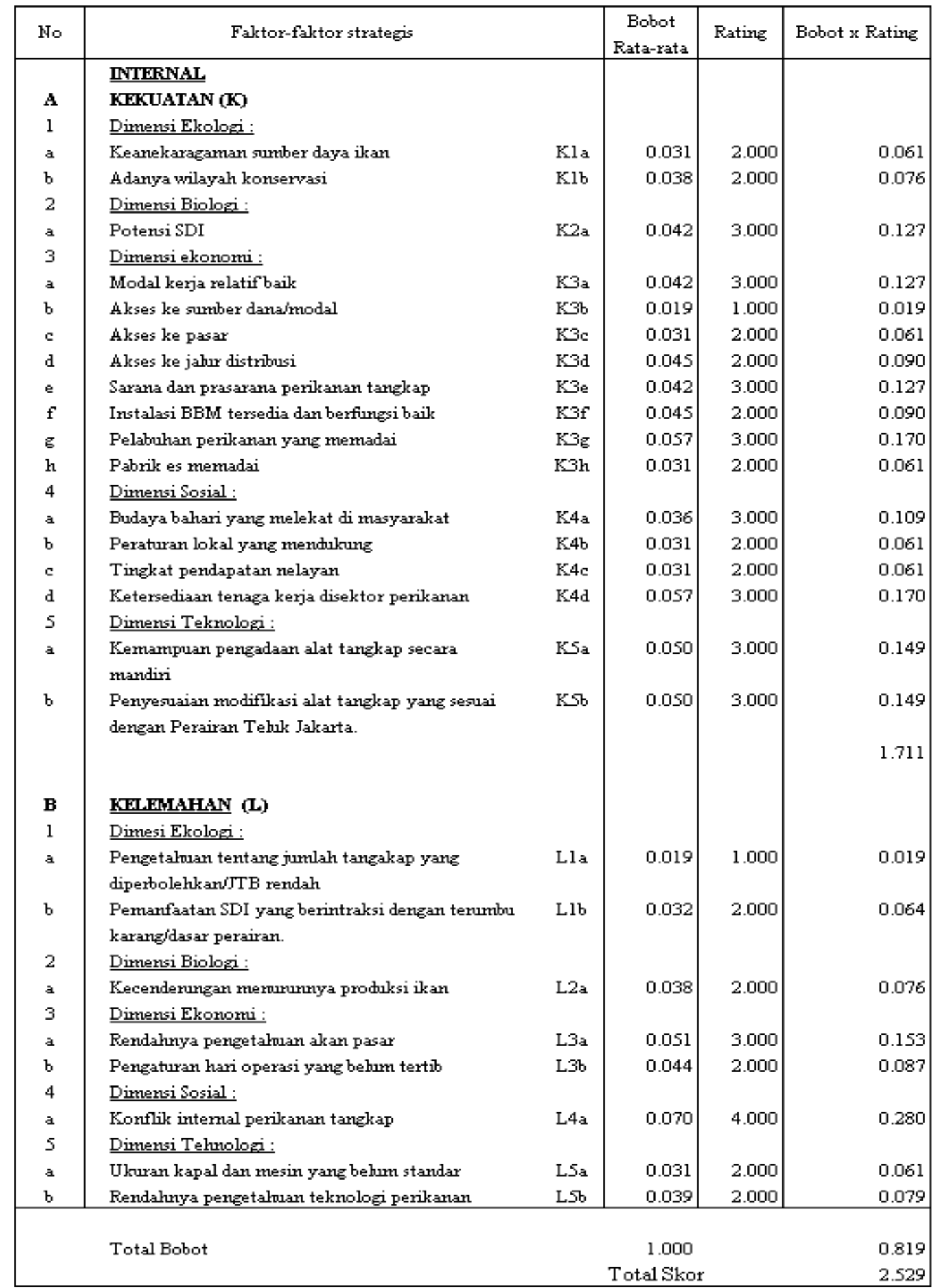

Keterangan :

$\mathrm{K} 1$, K2, K3, K4, dan K5 adalah masing-masing kekuatan dari dimensi ekologi, biologi, ekonomi, sosial dan teknologi. L1, L2, L3, L4, dan L5 adalah masing-masing kelemahan dari dimensi ekologi, biologi, ekonomi, sosial dan teknologi 
Tabel 2. Matriks Faktor Strategi Eksternal (EFAS)

\begin{tabular}{|c|c|c|c|c|c|}
\hline No & \multicolumn{2}{|l|}{ Faktor-faktor strategis } & $\begin{array}{c}\text { Bobot } \\
\text { Rata-rata }\end{array}$ & Rating & Bobot $\mathrm{x}$ Rating \\
\hline & EKSTERNAL & & & & \\
\hline $\mathbf{A}$ & PELUANG (P): & & & & \\
\hline 1 & Dimensi Ekologi : & & & & \\
\hline a & Adanya berbagai program penyelamatan & $\mathrm{Pla}$ & 0.047 & 2.000 & 0.093 \\
\hline & lingkungan ekologi (terumbu karang) & & & & \\
\hline 2 & Dimensi Biologi: & & & & \\
\hline a & $\begin{array}{l}\text { Konservasi terhadap jenis binatang laut } \\
\text { tertentu (penyu sisik) }\end{array}$ & $\mathrm{P} 2 \mathrm{a}$ & 0.039 & 1.000 & 0.039 \\
\hline 3 & Dimensi Ekonomi: & & & & \\
\hline a & Tingginya permintaan akan komoditi perikanan di dunia & P3a & 0.093 & 4.000 & 0.373 \\
\hline $\mathrm{b}$ & $\begin{array}{l}\text { Kedekatan dgn pasar potensial DKI Jakarta } \\
\& \text { jahur ekspor }\end{array}$ & $\mathrm{P} 3 \mathrm{~b}$ & 0.086 & 4.000 & 0.344 \\
\hline c & Promosi potensi perikanan oleh PEMDA & $\mathrm{P} 3 \mathrm{c}$ & 0.063 & 3.000 & 0.188 \\
\hline d & Naiknya trend utk investasi dibidang perikanan & P3d & 0.046 & 2.000 & 0.093 \\
\hline 4 & Dimesi Sosial: & & & & \\
\hline a & Kondisi sosial politik yang kondusif di lokasi & P4a & 0.039 & 2.000 & 0.079 \\
\hline 5 & Dimensi Teknologi: & & & & \\
\hline a & $\begin{array}{l}\text { Perkembangan teknologi dan modifikasi alat } \\
\text { penangkapan ikan yang ramah lingkungan di } \\
\text { duria }\end{array}$ & PSa & 0.047 & 2.000 & 0.093 \\
\hline $\mathbf{B}$ & ACAMAN (A): & & & & 1.302 \\
\hline 1 & Dimensi Ekologi: & & & & \\
\hline a & Ide zonasi/khuster pemanfaatan wilayah laut & Ala & 0.069 & 3.000 & 0.208 \\
\hline $\mathrm{b}$ & Tingkat Pencemaran perairan yang tinggi & Alb & 0.038 & 1.000 & 0.038 \\
\hline$c$ & $\begin{array}{l}\text { Degradasi fungsi ekosistem laut dan pesisir } \\
\text { akibat alih fungsi alam }\end{array}$ & Alc & 0.031 & 1.000 & 0.031 \\
\hline 2 & Dimensi Biologi: & & & & \\
\hline a & $\begin{array}{l}\text { Punahnya spesies tertentu dan meningkatnya } \\
\text { spesies tertentu non ekonomis }\end{array}$ & A2a & 0.069 & 3.000 & 0.207 \\
\hline $\mathrm{b}$ & $\begin{array}{l}\text { Faktor nosiman yg mengakibatkan ada waktu } \\
\text { ikan melimpah dan saat kekurangan ikan }\end{array}$ & $\mathrm{A} 2 \mathrm{~b}$ & 0.070 & 3.000 & 0.210 \\
\hline 3 & Dimensi Ekonomi: & & & & \\
\hline a & $\begin{array}{l}\text { Saat ikan melimpah harga cenderung turum } \\
\text { dan saat ikan langka harga sangat tinggi }\end{array}$ & A3a & 0.055 & 2.000 & 0.110 \\
\hline 4 & Dimensi Sosial: & & & & \\
\hline a & $\begin{array}{l}\text { Rendahnya kemampuan Adopsi IPTEK untuk kegiatan } \\
\text { perlindungan biota. }\end{array}$ & A4a & 0.077 & 4.000 & 0.310 \\
\hline 5 & Dimensi Teknologi: & & & & \\
\hline a & $\begin{array}{l}\text { Pengzunaan teknologi destruktif oleh nelayan } \\
\text { pendatang (misal : bahan peledak) }\end{array}$ & ASa & 0.061 & 2.000 & 0.122 \\
\hline $\mathrm{b}$ & $\begin{array}{l}\text { Persaingan akibat teknologi penangkapan ikan } \\
\text { lebih modem. }\end{array}$ & $\mathrm{A} S \mathrm{~b}$ & 0.070 & 3.000 & 0.210 \\
\hline & Total Bobot & & 1.000 & & 1.444 \\
\hline & & & Total Skor & & 2.747 \\
\hline
\end{tabular}

Keterangan :

$\mathrm{P} 1, \mathrm{P} 2, \mathrm{P} 3, \mathrm{P} 4$, dan $\mathrm{P} 5$ adalah masing-masing peluang dari dimensi ekologi, biologi, ekonomi, sosial dan teknologi. A1, A2, A3, A4, dan A5 adalah masing-masing ancaman dari dimensi ekologi, biologi, ekonomi, sosial dan teknologi 
Tabel 3. Matrik SFAS (Strategic Factor Analysis Summary)

\begin{tabular}{|c|c|c|c|c|c|}
\hline No & Faktor-faktor strategis & $\begin{array}{c}\text { Bobot } \\
\text { Rata- } \\
\text { rata }\end{array}$ & Rating & Skor & Ket \\
\hline $\mathbf{A}$ & INTERNAL & \multirow{6}{*}{0.042} & \multirow{6}{*}{3.0} & \multirow{6}{*}{0.127} & \multirow{6}{*}{$\mathrm{K} 2 \mathrm{a}$} \\
\hline & KEKUATAN (K) & & & & \\
\hline 1 & Dimensi Ekologi : & & & & \\
\hline 2 & Dimensi Biologi : & & & & \\
\hline a & Potensi SDI & & & & \\
\hline 3 & Dimensi ekonomi : & & & & \\
\hline a & Modal kerja relatif baik & 0.042 & 3.0 & 0.127 & K3a \\
\hline $\mathrm{e}$ & Sarana dan prasarana perikanan tangkap & \multirow[t]{2}{*}{0.042} & \multirow[t]{2}{*}{3.0} & \multirow[t]{2}{*}{0.127} & \multirow[t]{2}{*}{ K3e } \\
\hline 4 & Dimensi Sosial : & & & & \\
\hline $\mathrm{g}$ & Ketersediaan tenaga kerja disektor perikanan & \multirow[t]{2}{*}{0.057} & \multirow[t]{2}{*}{3.0} & \multirow[t]{2}{*}{0.170} & \multirow[t]{2}{*}{$\mathrm{K} 4 \mathrm{~g}$} \\
\hline 5 & Dimensi Teknologi: & & & & \\
\hline $\mathrm{a}$ & Kemampuan pengadaan alat tangkap secara mandiri & 0.050 & 3.0 & 0.149 & $\mathrm{~K} 5 \mathrm{a}$ \\
\hline $\mathrm{b}$ & Penyesuaian alat tangkap yang sesuai dgn & \multirow[t]{4}{*}{0.050} & \multirow[t]{4}{*}{3.0} & \multirow[t]{4}{*}{0.149} & \multirow[t]{4}{*}{$\mathrm{K} 5 \mathrm{~b}$} \\
\hline & Perairan Teluk Jakarta secara mandiri & & & & \\
\hline & KELEMAHAN (L) & & & & \\
\hline 1 & Dimesi Ekologi: & & & & \\
\hline a & Pengetahuan tentang jumlah tangakap yang & 0.019 & 1.0 & 0.019 & L1a \\
\hline $\mathrm{b}$ & $\begin{array}{l}\text { diperbolehkan/JTB rendah } \\
\text { Pemanfaatan SDI yg berinteraksi dgn terumbu karang / } \\
\text { dasar perairan }\end{array}$ & \multirow[t]{2}{*}{0.032} & \multirow[t]{2}{*}{2.0} & \multirow[t]{2}{*}{0.064} & \multirow[t]{2}{*}{ L1b } \\
\hline 2 & Dimensi Biologi : & & & & \\
\hline a & 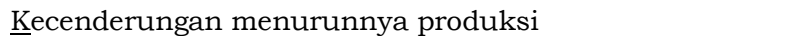 & \multirow[t]{4}{*}{0.038} & \multirow[t]{4}{*}{2.0} & \multirow[t]{4}{*}{0.076} & L2a \\
\hline 3 & Dimensi Ekonomi : & & & & \\
\hline 4 & Dimensi Sosial : & & & & \\
\hline 5 & Dimensi Tehnologi : & & & & \\
\hline a & Ukuran kapal dan mesin yang belum standar & 0.030 & 2.0 & 0.060 & L5a \\
\hline B & EKSTERNAL & & & & \\
\hline & PELUANG (P): & & & & \\
\hline 1 & Dimensi Ekologi : & & & & \\
\hline 2 & Dimensi Biologi : & & & & \\
\hline 3 & Dimensi Ekonomi : & & & & \\
\hline a & $\begin{array}{l}\text { Tingginya permintaan akan komoditi perikanan di dunia } \\
\text { Kedekatan dgn pasar potensial DKI Jakarta } \& \text { jalur }\end{array}$ & 0.093 & 4.0 & 0.373 & P3a \\
\hline $\mathrm{b}$ & $\begin{array}{l}\text { ekspor } \\
\text { Promosi potensi perikanan dan wisata bahari oleh }\end{array}$ & 0.086 & 4.0 & 0.344 & P3b \\
\hline c & PEMDA & 0.063 & 3.0 & 0.188 & P3c \\
\hline 4 & Dimesi Sosial : & & & & \\
\hline 5 & Dimensi Teknologi: & & & & \\
\hline & ACAMAN (A): & & & & \\
\hline 1 & Dimensi Ekologi : & & & & \\
\hline a & $\begin{array}{l}\text { Tingkat pencemaran di perairan yang tinggi } \\
\text { Degradasi ekosistem laut \& pesisir akibat alih fungsi }\end{array}$ & 0.038 & 1.0 & 0.038 & A1a \\
\hline $\mathrm{b}$ & lahan & 0.031 & 1.0 & 0.031 & A1b \\
\hline 2 & Dimensi Biologi : & & & & \\
\hline 3 & Dimensi Ekonomi : & & & & \\
\hline a & $\begin{array}{l}\text { Saat ikan melimpah harga cenderung turun } \\
\text { dan saat ikan langka harga sangat tinggi }\end{array}$ & 0.055 & 2.0 & 0.110 & A3a \\
\hline 4 & Dimensi Sosial : & & & & \\
\hline 5 & Dimensi Teknologi : & & & & \\
\hline a & Penggunaan teknologi destruktif oleh nelayan pendatang & 0.061 & 2.0 & 0.122 & A5a \\
\hline & TOTAL & 0.768 & 40.0 & 2.152 & \\
\hline
\end{tabular}




\subsection{Tingkat Keberlanjutan Pengelolaan Perikanan Tangkap di Teluk Jakarta}

Total skor matriks IFAS adalah 2,529 dan mariks EFAS adalah 2,747, jika dipetakan pada matriks IE maka titik temu kedua angka skor tersebut berada pada sel $\mathrm{V}$ (Gambar 1) yang berarti status keberlanjutan pengelolaan perikanan tang-kap di
Teluk Jakarta pada tahap pertumbuhan yang membutuhkan strategi pengelolaan konsentrasi secara horizontal, yaitu dengan melaksanakan koordinasi dengan instansi/ pihak lain yang bertang-gung jawab atas pengelolaan wilayah pesisir dan perairan di Teluk Jakarta.

Total Skor dari Kelompok Internal

\begin{tabular}{|c|c|c|c|c|}
\hline \multirow{3}{*}{$\begin{array}{l}\text { Total Skor dari } \\
\text { Kelompok } \\
\text { Eksternal }\end{array}$} & Tinggi & $\begin{array}{c}\text { I } \\
\text { Pertumbuhan } \\
\text { Konsentrasi } \\
\text { integrasi vertikal }\end{array}$ & $\begin{array}{c}\text { II } \\
\text { Pertumbuhan } \\
\text { Konsentrasi integrasi } \\
\text { horizontal }\end{array}$ & $\begin{array}{c}\text { III } \\
\text { Penciutan } \\
\text { Turnaraound }\end{array}$ \\
\hline & Sedang & $\begin{array}{c}\text { IV } \\
\text { Stabilitas } \\
\text { Hati-hati }\end{array}$ & $\begin{array}{c}\mathrm{V} \\
\text { Pertumbuhan } \\
\begin{array}{c}\text { Konsentrasi integrasi } \\
\text { horizontal }\end{array}\end{array}$ & $\begin{array}{c}\text { VI } \\
\text { Penciutan } \\
\text { Divestasi }\end{array}$ \\
\hline & \multirow[t]{2}{*}{ Rendah } & $\begin{array}{c}\text { VII } \\
\text { Pertumbuhan } \\
\text { Diversifikasi } \\
\text { konsentrik }\end{array}$ & $\begin{array}{c}\text { VIII } \\
\text { Pertumbuhan } \\
\text { Difersifikasi } \\
\text { perluasan }\end{array}$ & $\begin{array}{c}\text { IX } \\
\text { Penciutan } \\
\text { Likuidasi }\end{array}$ \\
\hline & & Tinggi & Rata-rata & Lemah \\
\hline
\end{tabular}

Gambar 1. Matriks internal-eksternal (IE)

\subsection{Analisis SWOT}

Alternatif strategi pengembangan dihasilkan dari matirks SWOT yang merupakan keluaran dari analisis SWOT. Alternatif strategi dibutuhkan untuk mendukung keberlanjutan pengelolaan perikanan tangkap ke arah yang lebih baik, dirumuskan dari tujuh belas faktor dominan yang mempengaruhi kegiatan perikanan tangkap di Teluk Jakarta menjadi delapan alternatif strategi pengelolaan, seperti ditunjukkan pada Tabel 4.

Alternatif strategi pengelolaan pada Tabel 4 dapat dijelaskan :

(1) SO strategi :

1) Pemberdayaan SDM di bidang perikanan melalui penyuluhan teknis dan manajemen untuk pemanfaatan potensi SDI;

2) Peningkatan kualitas produk melalui diversifikasi produk untuk memenuhi permintaan komoditi perikanan yang tinggi;

3) Peningkatan kemampuan nelayan mandiri melalui kemudahan akses ke fasilitas modal, jalur distribusi dan pasar.
(2) WO strategi :

Peningkatan pengawasan melekat terhadap aktivitas pemanfaatan sumberdaya ikan serta area konservasi dalam upaya tercapainya SDI berkelanjutan.

(3) ST strategi :

1) Penyuluhan kepada nelayan terhadap pentingnya kawasan konservasi dan manfaatnya bagi kelestarian SDI;

2) Menajemen terpadu untuk mempertahankan dan peningkatan fungsi ekosistem perairan terutama pencegahan terjadi pencemaran yang berkelanjutan.

(4) WT strategi :

1) Standardisasi terhadap perikanan skala kecil untuk peningkatan produktivitas kapal dan mutu ikan;

2) Pengaturan hari operasi dengan penerapan "closed - open season" untuk menjaga stabilitas jumlah dan harga ikan di pasar. 
Tabel 4. Matriks SWOT

\begin{tabular}{|c|c|c|}
\hline & $\begin{array}{l}\text { KKKUATAN (K) } \\
\text { I Dimensi Ekologi: } \\
\text { a Keanekaragaman sumber daya ikan } \\
\text { b Adanya wilayah konservasi } \\
2 \text { Dimensi Biologi: } \\
\text { a Potensi SDI } \\
3 \text { Dimensi ekonomi: } \\
\text { a Modal kerja relatif baik } \\
\text { b Akses ke sumber dana/modal } \\
\text { c Akses ke pasar } \\
\text { d Akses ke jahur distribusi } \\
\text { e Sarana dan prasarana perikanan tangkap } \\
\text { f Instalasi BBM tersedia dan berfungsi baik } \\
\text { g Pelabuhan perikanan yang memadai } \\
\text { h Pabrik es memadai } \\
4 \text { Dimensi Sosial: } \\
\text { a Budaya bahari yang melekat di masyarakat } \\
\text { b Peraturan lokal yang mendukung } \\
\text { c Tingkat pendapatan nelayan } \\
\text { d Ketersediaan tenaga kerja disektor perikanan } \\
5 \text { Penyesuaian alat tangkap yang sesuai dgn } \\
\text { a Kemampuan pengadaan alat tangkap secara } \\
\text { mandiri } \\
\text { b Penyesuaian modifikasi alat tangkap yang sesuai } \\
\text { dengan Perairan Tehuk Jakarta. }\end{array}$ & \begin{tabular}{|l|} 
KKILEMAHAN (L) \\
I Dimesi Ekologi: \\
a Pemanfaatan SDI yang berintraksi dengan terumbn \\
diperbolehkan/JTB rendah \\
b Interaksi pemanfatan dgn terumbu karang / \\
dasar perairan. \\
2 Dimensi Biologi: \\
a Kecenderungan mernumunya produksi ikan \\
3 Dimensi Ekonomi: \\
a Rendahnya pengetalnuan akan pasar \\
b Pengaturan hari operasi yang behum tertib \\
4 Dimensi Sosial: \\
a Konflik intemal perikanan tangkap \\
5 Dimensi Tehnologi: \\
a Ukuran kapal dan mesin yang behm standar \\
b Rendahnya pengetalnaan teknologi perikanan
\end{tabular} \\
\hline $\begin{array}{l}\text { PELUANG (P): } \\
\text { 1 Dimensi Ekologi: } \\
\text { a Adanya berbagai program penyelamatan } \\
\text { lingkungan ekologi (terumbu karang) } \\
2 \text { Dimensi Biologi: } \\
\text { a Konservasi terhadap jenis binatang laut } \\
\text { tertentu (penyu sisik) } \\
3 \text { Dimensi Ekonomi: } \\
\text { a Tingginya permintaan akan komoditi perikanan di } \\
\text { b Kedekatan dgn pasar potensial DKI Jakarta } \\
\text { \& jahur ekspor } \\
\text { c Promosi potensi perikanan oleh PEMDA } \\
\text { d Naiknya trend utk investasi dibidang perikanan } \\
4 \text { Dimesi Sosial: } \\
\text { a Kondisi sosial politik yang kondusif di lokasi } \\
5 \text { Dimensi Teknologi: } \\
\text { a Perkembangan teknologi dan modifikasi alat } \\
\text { penangkapan ikan yang ramah linghungan di } \\
\text { dunia }\end{array}$ & 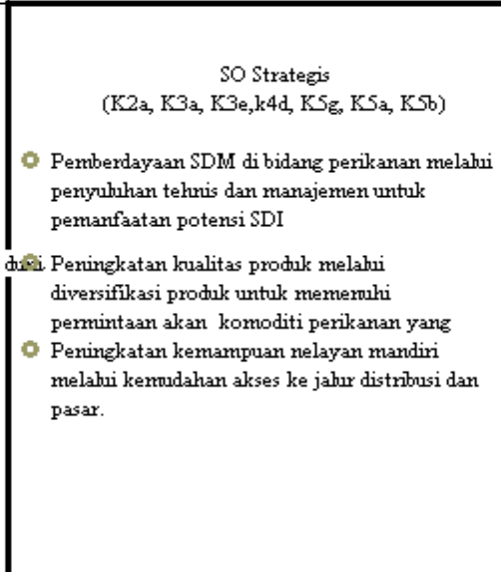 & $\begin{array}{l}\text { WO Strategis } \\
\qquad \text { (P3a, P3b, P3c) } \\
\text { O Peningkatan pengawasan melekat terhadap } \\
\text { pemanfaatan sumberdaya ikan serta di area } \\
\text { konservasi terutama dalam permanfaatan dengan } \\
\text { alat tangkap yang destruktif }\end{array}$ \\
\hline $\begin{array}{l}\text { ACAMAN (A): } \\
\text { 1 Dimensi Ekologi: } \\
\text { a Ide zonasilkhuster pemanfaatan wilayah laut } \\
\text { b Tingkat Pencemaran perairan yang tinggi } \\
\text { c Degradasi fungsi ekosistem laut dan pesisir } \\
\text { akibat alih fungsi alam } \\
2 \text { Dimensi Biologi: } \\
\text { a Punahnya spesies tertentu dan meningkatnya } \\
\text { spesies tertentu non ekonomis } \\
\text { b Faktor rosiman yg mengakibatkan ada waktu } \\
\text { ikan melimpah dan saat kekurangan ikan } \\
3 \text { Dimensi Ekonomi: } \\
\text { a Saat ikan melimpah harga cendenung turun } \\
\text { dan saat ikan langka harga sangat tinggi } \\
4 \text { Dimensi Sosial: } \\
\text { a Rendahnya kemampuan Adopsi IPTEK untuk keg } \\
\text { perlindungan biota. } \\
\text { 5 Dimensi Teknologi: } \\
\text { a Penggunaan teknologi destruktif oleh nelayan } \\
\text { pendatang (misal : bahan peledak) } \\
\text { b Persaingan akibat teknologi penangkapan ikan } \\
\text { lebih modem. }\end{array}$ & $\begin{array}{l}\text { ST Strategis } \\
\text { (Lla, L1b, L2a, LSa) } \\
\text { o Penyuhuhan kepada nelayan terhadap } \\
\text { pentingnya kawasan konservasi dan manfaatnya } \\
\text { bagi kelestarian sumberdaya ikan } \\
\text { - Manajemen terpadu untuk mempertahankan dan } \\
\text { peningkatan fungsi ekosistem perairan terutama } \\
\text { pencegahan terjadi pencemaran yang }\end{array}$ & $\begin{array}{c}\text { WT Strategis } \\
\text { (Ala, A 1b, A3a, ASa) } \\
\text { O Standarisasi terhadap perikanan ukuran kecil } \\
\text { untuk peningkatan produktifitas kapal dan routu } \\
\text { - Pengaturan hari operasi dengan penerapan } \\
\text { "closed-open season" untuk mrnjaga stabilitas } \\
\text { jumlah dan harga ikan di pasar }\end{array}$ \\
\hline
\end{tabular}

\section{PEMBAHASAN}

\subsection{Faktor Internal Pengelolaan Peri- kanan Tangkap di Teluk Jakarta}

Faktor keanekaragaman hayati/ jenis ikan dan terdapatnya wilayah konservasi pada Tabel 1 merupakan dimensi ekologi yang menjadi kekuatan dalam pengelolaan perikanan tangkap di Teluk Jakarta. Hal ini karena keanekaragaman dan kegiatan-kegiatan konservasi tersebut dikelola secara permanen di lokasi, yaitu oleh UPT Taman Nasional Laut Kepulauan Seribu (TN(L) Kep. Seribu), Dirjen Perlindungan Hutan dan Konservasi Alam, 
Departemen Kehutanan. Kawasan TN (L) Kep. Seribu terdiri dari perairan laut yang mempunyai pulau-pulau karang yang terbentuk di atas koloni binatang karang yang sudah mati, mencakup 78 pulau yang tersebar dari Utara ke Selatan. Menurut Berkes (1994), pengelolaan kawasan konservasi pesisir dan laut harus melibatkan masyarakat lokal yang ada, sehingga mereka merasa memiliki, ikut melestarikan, dan ikut mencegah kegiatan pemanfaatan yang destruktif.

Wilayah perairan Jakarta merupa-kan bagian dari Wilayah Pengelolaan Perikanan Laut Jawa (WPP-RI 712). Potensi SDI menjadi faktor kekuatan, berdasarkan data potensi di WPP-RI 712) tersedia 1130,8 ribu ton/tahun dengan tingkat pemanfaatan dikategorikan penuh (DJPT-DKP 2009a). Namun demikian, adanya upaya konservasi TN (L) Kep. Seribu yang erat kaitannya dengan pelestarian sumber daya ikan dan biota laut lainnya sangat berpengaruh terhadap pemeliharaan stok dan penyediaan ikan bagi aktivitas penangkapan ikan di perairan Teluk Jakarta. Menurut Hendriwan et al. (2008), stok sumberdaya sangat sensitif terhadap kegiatan pemanfaatan, apalagi yang melebih daya dukung potensi tersebut. Alokasi alat tangkap yang optimum namun tidak melebihi daya dukung akan dapat meningkatkan hasil tangkapan sekaligus tetap memelihara kelestarian sumberdaya ikan kawasan.

Modal kerja pada Tabel 1 merupakan komponen penting bagi operasional perikanan tangkap dari dimensi ekonomi. Secara umum, nelayan di Teluk Jakarta adalah nelayan pekerja, pemilik kapal yang memberikan seluruh modal operasional kapal dengan sistem gaji tetap dan bagi hasil. Nakhoda mendapat gaji dan komisi. Bagi hasil dengan bagian setiap anggota kapal satu bagian dan pemilik tiga bagian. Dari 3 bagian pemilik, satu bagian dibagi dua lagi yang menjadi porsi untuk pemilik dan nakhoda sebagai komisi. Nelayan mendapat bonus yang dihitung dari hasil timbangan sebesar Rp 500/kg.

Sarana dan prasarana perikanan tangkap di darat cukup memadai. Untuk nelayan kecil di pelabuhan pendaratan ikan di pulau Pramuka maupun pulau-pulau lainnya tidak ada pengenaan biaya tambat dan mendapat cool box tujuh buah serta mendapat tiga keranjang untuk menimbang (trish) yang berukuran 1 kuintal/25 kg. Pelabuhan di Teluk Jakarta (PPS Nizam Zachman) mempunyai fasilitas yang memadai untuk kegiatan perikanan skala besar (DJPT-DKP, 2009-b). Namun dari fasilitas tesebut juga ada yang kurang terawat atau nyaman, misalnya lokasi pelelangan ikan yang sering tergenang air, kolam pelabuhan pada beberapa bagian ada yang terlalu dangkal, dan lainnya. Meskipun terdapat kekurangan, secara umum pelabuhan perikanan tersebut telah mampu mendukung dengan baik kegiatan pendaratan dan pelelangan ikan selama ini dan merupakan pelabuhan perikanan terbesar di Indonesia.

Instalasi BBM merupakan komponen penting dalam mendukung kegiatan perikanan tangkap. Saat ini sudah tersedia instalasi BBM di TPI Kamal Muara, TPI Muara angke, TPI Cilincing, dan TPI Kalibaru namun tidak tersedia di TPI Pulau Pramuka (untuk nelayan di Kepulauan Seribu). Namun demikian, kondisi semua instalasi tersebut lebih memadai dibandingkan tempat lainnya di Indonesia.

Pengetahuan tentang Jumlah Tangkap yang Diperbolehkan/JTB rendah (Tabel 1) menjadi salah satu kelemahan bagi pengelolaan perikanan tangkap. Tingkat pemanfaatan SDI saat ini di Teluk Jakarta sudah mencapai 90\% lebih dari potensi SDI. Rendahnya pengetahuan dan kepedulian nelayan, menyebabkan dalam kegiatan penangkapan seringkali tidak mengindahkan keberadaan Kawasan Taman Nasional Laut Kepulauan Seribu. Masih adanya penggunaan bom untuk mencari ikan di area konservasi, terutama pada saat-saat sepi wisatawan yaitu pada hari Senin dan/atau Selasa. Hal ini terjadi karena daerah konservasi berada dekat dengan pemukiman dan diketahui banyak ikannya sehingga mendorong penduduk untuk menangkap ikan secara destruktif yang berinteraksi dengan terumbu karang/ dasar perairan.

Untuk ukuran kapal dan jenis mesin yang dipakai tidak ada standar tertentu. Para nelayan membuat kapal atas pengetahuan dan pengalaman mereka saja mulai dari ukuran kapal dan palka hingga jenis mesin yang dipakai. Belum ada suatu teknologi yang diadopsi untuk ukuran kapal dan palka dalam upaya mencapai produktifitas tinggi dan mempertahankan mutu ikan, hal ini disebabkan karena rendahnya pengetahuan akan teknologi perikanan tangkap. Sedangkan menurut Hendriwan et al. (2008), kapal yang dioperasikan hendaknya berukuran standar, sehingga dapat dioperasikan sesuai prosedur baku dan 
memudahkan menentukan alokasi optimal kapal.

\subsection{Faktor Eksternal Pengelolaan Peri- kanan Tangkap di Teluk Jakarta}

Adanya berbagai program dari berbagai pihak dalam upaya penyelamatan lingkungan ekologi (Tabel 2) termasuk peluang besar dalam pengelolaan perikanan tangkap di Teluk Jakarta. Hal ini ditunjukkan oleh penanaman pohon mangrove, lamun, terumbu karang buatan baik oleh masyarakat setempat, pemerintah, swasta, LSM atau hasil kerjasama dengan institusi internasional dan dalam negeri.

Adanya perlindungan terhadap keberadaan jenis binatang laut tertentu (Tabel 2) juga peluang dari dimensi biologi. Dengan upaya perlindungan terhadap penyu sisik, maka perlindungan dan pembinaan dilakukan terhadap habitatnya yaitu Pulau Peteloran Timur, Gosong Rengat dan Pulau Belanda, Gosong Sepa, Gosong Butun. Pembinaan juga dilakukan pada pulau pemukiman yaitu Pulau Pramuka, Pulau Kelapa dan Pulau Harapan dengan cara pembersihan pantai peneluran penyu, sehinga memudahkan penyu sisik mendarat di pantai saat akan bertelur. Menurut Ruddle et al. (1992), kegiatan perlindungan dan pembinaan merupakan timbal balik yang diberikan oleh manusia kepada alam, dimana manusia (costumer) membutuhkan alam bagi kehidupannya, dan alam juga membutuhkan perlindungan manusia. Perlindungan semacam itu, tentu akan berpengaruh terhadap ekosistem perairan yang mempunyai dampak positif bagi biota laut lainnya khususnya ikan. Selain perlindungan terhadap penyu sisik, perlindungan juga dilakukan terhadap ikan kerapu hidup bersama habitatnya.

Meningkatnya permintaan dunia akan produk/komoditi perikanan dan kedekatan dengan pasar potensial DKI Jakarta dan jalur ekspor juga merupakan peluang dari dimensi ekonomi. Menurut DKPP (2009), lebih dari $80 \%$ kebutuhan ikan segar ibukota Jakarta dan sekitarnya berasal dari pelabuhan atau tempat pelelangan ikan yang terdapat di Teluk Jakarta, walupun sebagian besar berasal dari aktifitas penangkapan di luar Teluk Jakarta. Komoditi ikan tujuan eskpor dilakukan melalui Pelabuhan Tanjung Priok dengan menggunakan contact freezer dan melalui Bandara International SoekarnoHatta dengan menggunakan jasa angkut udara.
Kondisi sosial politik yang kon-dusif di wilayah di Teluk Jakarta sebagai akibat upaya pertahanan stabilitas dan situasi yang kondusif di ibu kota negara menjadikan Teluk Jakarta yang merupakan bagian dari Provinsi DKI Jakarta mendapat imbas positif, yaitu keamanan dan kenyamanan untuk berusaha. Dukungan komponen kondusifitas kondisi sosial politik berpengaruh terhadap pengelolaan perikanan tangkap di Teluk Jakarta.

Ide zonasi/kluster pemanfaatan wilayah laut merupakan ancaman karena membuat sekat-sekat dalam pengelolaan perikanan tangkap. Sampai saat ini kenyataanya, Provinsi DKI Jakarta tidak memiliki data potensi perikanan untuk wilayah pengelolaan perikanan yang dalam yuridiksi kewenangan provinsi. Padahal penetapan kontribusi pihak swasta kepada negara, potensi perikanan dijadikan dasar penghitungan pembagian kluster untuk dikelola swasta. Sedangkan menurut Sheppard et al. (1995), pemetaan atau pengklusteran kawasan dapat mengganggu kegiatan konservasi wilayah laut, dimana wilayah akan dikonservasi menjadi tersekatsekat, padahal obyek konservasi (ikan, sumberdaya hayati laut) bersifat mobile melintasi batas wilayah.

Tingkat pencemaran yang tinggi baik itu berasal dari sampah maupun limbah industri dan tumpahan minyak sangat tinggi di Teluk Jakarta. Sebagai indikator pada tahun 2003 sampah dari aktifitas darat yang terbawa arus sampai ke perairan Pulau Untung Jawa, tahun 2004 hingga ke perairan Pulau Pari dan tahun 2005 sudah sampai ke perairan Pulau Pramuka. Hal ini menunjukkan volume limbah sampah yang dibuang ke Teluk Jakarta tiap tahun meningkat. Estimasi sampah pada tahun 2005 adalah 10.220 ton/per hari (Bappeda Jakarta, 2003). Menurut Anna (2003), pencemaran oleh limbah dan sampah tersebut telah menyebabkan penurunan total benefit perikanan Teluk Jakarta sekitar Rp 691,46 juta per tahun.

Punahnya atau berkurangnya spesies ikan tertentu dan meningkatnya spesies tertentu/non ekonomis, merupakan salah satu indikator terjadinya overfishing di Teluk Jakarta. Penurunan dan peningkatan jenis ikan tertentu di Teluk Jakarta terjadi pada jenis ikan bandeng laut yang menurun dan meningkatnya jenis ikan pelagis yaitu lemuru (Syamsubagiyo N. 30 Nopember 2009. wawancara). Faktor lain 
yang merupakan ancaman eksternal bagi keberlanjutan perikanan tangkap adalah faktor musiman yang berpengaruh terhadap kehidupan biota laut.

Dimensi ekologi, faktor musiman tersebut diatas juga mempengaruhi dimensi ekonomi dalam hal harga ikan, dimana saat ikan melimpah harga cenderung turun dan saat ikan langka harga sangat tinggi. Untuk menciptakan kestabilan harga yang berpengaruh terhadap pendapatan nelayan, diperlukan suatu pengaturan ketersediaan volume ikan untuk jenis-jenis ikan komersial.

Penggunaan teknologi destruktif oleh nelayan pendatang cukup banyak terjadi di perairan Teluk Jakarta. Dari hasil survai, hal ini sudah berlangsung lama, dimana nelayan yang berasal dari Banten dan hidup menetap di lokasi sering menempuh cara tersebut bila hasil tangkapan sulit di dapat. Bagi sebagian nelayan pendatang yang sudah mengerti akan bahaya penggunaan bahan peledak maupun sianida, beralih ke alat tangkap bubu yang merupakan alat tangkap statis untuk menangkap jenis ikan yang sama yaitu ikan karang.

\subsection{Status Keberlanjutan Pengelolaan Perikanan Tangkap di Teluk Jakarta dan Strategi Penge-lolaanya}

Jumlah skor IFAS pengelolaan perikanan tangkap di Teluk Jakarta adalah 2.529, artinya pengelolaan perikanan tangkap di Teluk Jakarta berada pada posisi dibawah indikator "rata-rata" atau kurang baik dalam hal merespons faktor-faktor internal yang mempengaruhi pengelolaan perikanan di Teluk Jakarta. Jumlah skor EFAS-nya adalah 2.747, artinya pengelolaan perikanan tangkap di Teluk Jakarta berada pada posisi dibawah indikator "ratarata" atau kurang baik dalam hal merespons faktor-faktor eksternal yang mempengaruhi pengelolaan perikanan di Teluk Jakarta.

Berdasarkan output skor matriks IFAS dan EFAS (Gambar 1), diketahui bahwa status keberlanjutan pengelolaan perikanan tangkap di Teluk Jakarta berada pada sel V (pertumbuhan). Sesuai dengan ketentuan SWOT, bahwa suatu kegiatan pengelolaan dapat dilanjutkan bila minimal berasal kondisi pertumbuhan (total skor dimensional internal $>2$ dan total skor dimensional eksternal $>1$ ).

Skor matriks SFAS adalah 2.152, yang berarti dibawah indikator "rata-rata" atau kurang baik dalam hal merespons faktorfaktor internal dan eksternal yang berpengaruh terhadap keberlanjutan kebijakan pengelolaan perikanan tangkap di Teluk Jakarta. Dari hasil rangkuman matriks SFAS terdapat 17 (tujuh belas) faktor penting yang mempengaruhi pengelolaan perikanan tangkap di Teluk Jakarta, terdiri dari enam faktor kekuatan, empat faktor kelemahan, tiga faktor peluang dan empat faktor ancaman. Ketujuh belas faktor tersebut digunakan dalam memformulasikan strategi pengelolaan perikanan tangkap.

\subsection{Strategi Pengembangan Pengelolaan}

Menurut Hendriwan et al. (2008), dalam suatu pengelolaan, jika tingkat keberlanjutan perikanan "kurang baik" maka akan memerlukan upaya pencegahan dan penanganan dini dari pelaku pengelolaan. Karena bila tidak, komponen ekosistem yang kurang baik kondisinya akan menganggu perkembangan komponen lain yang bergantung kepadanya seperti sumberdaya ikan, kegiatan pemanfaatan, dan kesejahteraan masyarakat. Dengan demikian akan mengganggu keberlanjutan pengelolaan itu sendiri.

Terkait dengan status pengelolaan perikanan tangkap di Teluk Jakarta yang memiliki status dalam pertumbuhan, maka kebijakan pengelolaan perikanan tangkap dapat dilanjutkan dengan mengarah kepada perbaikan. Implikasi dari hal ini adalah berusaha untuk mempertahankan berbagai hal yang menjadi kekuatan dan memanfaatkan berbagai peluang yang ada, serta memperbaiki berbagai hal yang menjadi kelemahan dan meminimalisasi pengaruh berbagai ancaman yang ada. Hal ini dapat dilakukan dengan melaksanakan berbagai strategi yang relevan dengan kondisi tersebut dalam kontrol manajemen yang baik (Sunarto et al. 1997).

Terdapat delapan alternatif strategi yang dirangkum dalam matriks SWOT untuk pengembangan pengelolaan perikanan tangkap di Teluk Jakarta. Dimana dalam pelaksanaannya dilakukan secara bertahap dan berdasarkan prioritas.

Dari kajian lanjutan dengan menggunakan Analysis Hierarchy Process (AHP) yang dilakukan menghasilkan strategi standarisasi perikanan ukuran kecil (SPUK) menjadi strategi prioritas pertama untuk dilakukan dalam mendukung perikanan tangkap berkelanjutan di Teluk Jakarta. Menurut Putra (2000), pembenahan kegiatan perikanan ukuran kecil dapat meng- 
hindari terjadi konflik pengelolaan, selain karena usaha perikanan kecil dilakukan sebagian besar oleh masyarakat setempat, dengan menghindari konflik maka keberlanjutan suatu pengelolaan perikanan tangkap dapat dilaksanakan.

\section{KESIMPULAN DAN SARAN}

\subsection{Kesimpulan}

Terdapat tujuh belas faktor internal dan eksternal yang dominan berpengaruh terhadap pengelolaan perikanan tangkap di Teluk Jakarta. Dari ketujuh belas faktorfaktor tersebut untuk lingkungan internal yang menjadi kekuatan dominan adalah dari dimensi sosial yaitu ketersediaan tenaga kerja di sektor perikanan, sedangkan kelemahan yang dominan adalah dari dimensi ekologi yaitu kurangnya pengetahuan dari pelaku perikanan tangkap tentang jumlah SDI yang diperbolehkan. Lingkungan eksternal yang menjadi peluang dominan adalah dari dimensi ekonomi yaitu tingginya permintaan akan komoditi perikanan sebagai peluang pasar, sedangkan ancaman yang dominan adalah dimensi ekologi yaitu degradasi ekosistem laut dan pesisir akibat alih fungsi lahan.

Matriks IE menunjukkan status keberlanjutan pengelolaan perikanan tangkap di Teluk Jakarta yaitu pada sel V, berarti dalam tahap pertumbuhan yang memerlukan strategi untuk konsentrasi secara horizontal. Kategori pengelolaan perikanan tangkap di Teluk Jakarta adalah "kurang baik", artinya kurang baik dalam hal merespons faktor internal maupun eksternal yang berpengaruh terhadap perikanan tangkap di Teluk Jakarta. Untuk alternatif strategi pengembangan pengelolaan, matriks SWOT menghasilkan delapan alternatif strategi yaitu: (1) Pemberdayaan SDM di bidang perikanan melalui penyuluhan teknis dan manajemen untuk pemanfaatan potensi SDI; (2) Peningkatan kualitas produk melalui diversifikasi produk untuk memenuhi permintaan komoditi perikanan yang tinggi; (3) Peningkatan kemampuan nelayan mandiri melalui kemudahan akses ke fasilitas modal, jalur distribusi dan pasar; (4) Peningkatan pengawasan melekat terhadap aktifitas pemanfaatan sumberdaya ikan serta area konservasi dalam upaya tercapainya SDI berkelanjutan; (5) Penyuluhan kepada nelayan terhadap pentingnya kawasan konservasi dan manfaatnya bagi kelestarian SDI; (6) Menajemen terpadu untuk mempertahankan dan peningkatan fungsi ekosistem perairan terutama pencegahan terjadi pencemaran yang berkelanjutan; (7) Standarisasi terhadap perikanan skala kecil untuk peningkatan produktivitas kapal dan mutu ikan; (8) Pengaturan hari operasi dengan penerapan "closed-open season" untuk menjaga stabilitas jumlah dan harga ikan di pasar.

\subsection{Saran}

Mengingat Teluk Jakarta mempunyai beragam fungsi dalam pemanfaatannya dan dihadapkan pada beragam permasalahan antara lain degradasi fungsi ekosistem, maka untuk mewujudkan pengelolaan perikanan tangkap yang berkelanjutan, pengambil kebijakan disarankan untuk melakukan koordinasi dengan berbagai pihak/instansi yang berwenang dalam mengeluarkan kebijakan terutama yang berkaitan dengan penggunaan lahan pesisir Jakarta Utara dan Kepulauan Seribu, melakukan upaya konservasi untuk ekosistem penting (mangrove dan biota laut) dan melakukan kajian stok ikan dalam lingkup provinsi DKI Jakarta.

\section{DAFTAR PUSTAKA}

Anna S. 2003. Model Embedded Dinamik Ekonomi Interaksi Perikanan-Pencemaran. [disertasi]. PPS IPB. Bogor. 388 hal.

[Bappeda Jakarta] Badan Perencana Daerah Pemerintah Provinsi DKI Jakarta. Pengelolaan Sampah. 2003. http://www.bappedajakarta.go.id/jk tbangun03.asp [1 Okt 2009].

Berkes, F. 1994. Property Rights and Coastal Fisheries, p.51-62. In Pomeroy, R.S. (ed.) Community Management and Common Property of Coastal Fisheries in Asia and The Pasific: Concepts, Methods and Experiences. ICLARM Conf. Proc. 45, $189 \mathrm{p}$.

Cochrane KL. 2002. A Fishery Manager's Guidebook. Management Measures and Their Application. Senior Fishery Resources Officer. Fishery Resources Division. FAO Fisheries Department. Rome. 231 p.

[DJPT-DKP] Direktorat Jenderal Perikan-an Tangkap, Departemen Kelautan dan Perikanan. 2009a. Keragaan Peri- 
kanan Tangkap di Laut di setiap Wilayah Pengelolaan Perikanan (WPP). Jakarta.

[DJPT-DKP] Direktorat Jenderal Perikanan Tangkap, Departemen Kelautan dan Perikanan. 2009b. Pelabuhan Perikanan Samudra Nizam Zachman Jakarta. Laporan Statistik 2008. Jakarta.

[DKPP] Dinas Kelautan dan Pertanian Provinsi DKI Jakarta. 2009. Data Perikanan DKI Jakarta tahun 1992 2008. Jakarta.

Hendriwan M, Sondita FA, Haluan J, dan Wiryawan B. 2008. Analisis Optimasi Pengelolaan Perikanan Tangkap dan Strategi Pengembangannya di Teluk Lampung. Buletin PSP 17(1) : 44-70. [Fakultas Perikanan dan Ilmu Kelautan, IPB, Bogor]

Muchtar A. 1999. Kebijakaan Pengembangan Perikanan Laut di Indonesia dalam Prosiding Seminar Tentang Oseanologi dan Ilmu Lingkungan Laut. Puslitbang Oseanografi LIPI. Jakarta. Hal : 1-7

[Pemkab Kep. Seribu] Pemerintah Kabupaten Kepulauan Seribu, Provinsi DKI Jakarta. Potensi dan Pemanfaatan Sumberdaya Perikanan Kelautan di Kabupaten Administrai Kepulauan Seribu, Provinsi DKI Jakarta. 2009. Pulau Pramuka, Kep. Seribu.

Putra S. 2000. Konflik Pengelolaan Sumber Daya Kelautan di Sulawesi Utara Dapat Mengancam Kelestarian Pemanfaatannya. Jurnal Depdagri Vol 12. Jakarta.

Radarwati S. 2003. Analisis Strategi Pembiayaan dalam Ekspansi Usaha pada PT Bahtera Adimina Samudra Tbk. [thesis]. Bogor. Program Pascasarjana. IPB. 140 hal.
Rangkuti F. 2008. Analisis SWOT Teknik Membedah Kasus Bisnis. PT Gramedia Pustaka Utama.

Roger KM. 1990. Strategic Market Planning. Allyn and Bacon. Simon and Schuster, Inc.

Ruddle K, Hviding E, and Johannes RE. 1992. Marine Resource Management In The Context of Customary Tenure. Marine Resource Economics (7), p. 249-273.

Rudianto. 2004. Analisis Konflik Pemanfaatan Lahan Wilayah Pesisir (studi kasus Pantai Utara Jakarta) [disertasi]. Bogor : Program Pascasarjana, Institut Pertanian Bogor. 292 hal.

Sheppard CRC, Matheson,K, Bythell JC, Edwards AJ, Murphy P, Blair-Myers C, and Blake B. 1995. Habitat Mapping in the Caribbean for Management and Conservation: use and assessment of aerial photography. Aquatic Con servation: Marine and Freshwater Ecosystems 5, p. 277-298.

Sonari SS. 17 Juli 2009. Bom Waktu Pencemaran Teluk Jakarta dan Kep. Seribu. Republika: http:// www. oseanografi.lipi.go.id/index $[20 \mathrm{Jul}$ 2009]

Sunarto K, Sutikno, Dulbahri. 1997. Kesesuaian Wilayah Perairan Laut untuk Budidaya Rumput Laut Jenis Eucheuma di Terumbu Karang Pulau Pari Teluk Jakarta. Geomatika. No. 1-2 hal 18-33.

Wheelen TL, Hunger JD. 2002. Strategic Management and Business Policy, Eight Edition. Prentice Hall. Upper Saddle River. New Jersey. 